\title{
CONTRIBUTION TO HYDRAULIC CHARACTERISTICS OF PLIO-PLEISTOCENE DEPOSITS OF THRIASSION PLAIN OF ATTICA
}

\author{
Hermides D. ${ }^{1}$, Mimides T. ${ }^{1} \dagger$ and Stamatis G. ${ }^{1}$ \\ ${ }^{\prime}$ Agriculture University of Athens, Department of Natural Resources Management and Agricultura \\ lEngineering 11855, Athens, Greece,dermides@aua.gr, stamatis@aua.gr
}

\begin{abstract}
The geological structure of Thriassion Plain is generally complex and has been affected at different times by many tectonic activities. The last ones are the neotectonic, which caused horsts and grabens structures. Geologic and tectonic structures have influenced the hydrogeological conditions and the groundwater flow. Hydraulic characteristics of Plio-Pleistocene deposits differ throughout their extent. In this study, pumping tests in Plio-Pleistocene deposits are represented and the hydraulic characteristics transmissivity $T$, storativity $S$ and hydraulic conductivity $K$ are assigned. Pumping tests, in 8 totally wells, were conducted in the dry period. Methods as Cooper-Jacob's, Theis's, Papadopoulos-Cooper's and Neuman's and last the Recovery method, are used to assign the hydraulic characteristics. These tests highlighted the Recovery method as the most reliable. Transmissivity T: $18-279.1 \mathrm{~m}^{2} / d$, storativity $S: 2.5 * 10^{-3}-3 * 10^{-2}$ and hydraulic conductivity $K: 0.4-25.1 \mathrm{~m} / \mathrm{d}$. Specific capacity is also determined ranging between $16-360 \mathrm{~m}^{3} / \mathrm{d} / \mathrm{m}$. This study contributes, essentially, in the approach of hydrogeological conditions of Thriassion Plain.
\end{abstract}

Keywords: Quaternary sediments, Groundwater pumping test.

\section{Пєрі́⿱亠乂 $\psi \eta$}

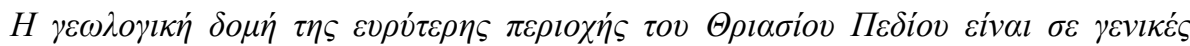

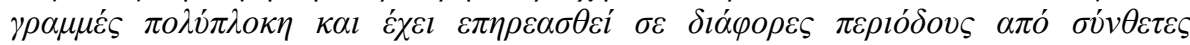

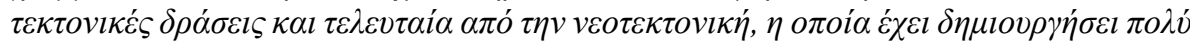

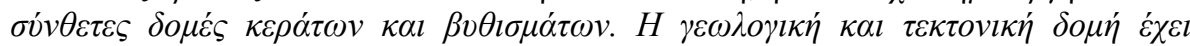

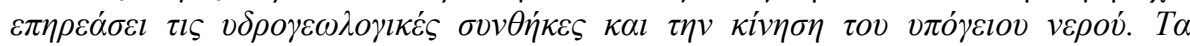

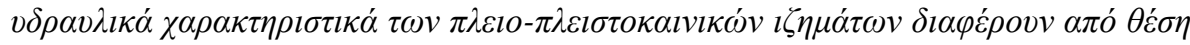

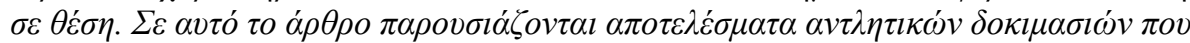

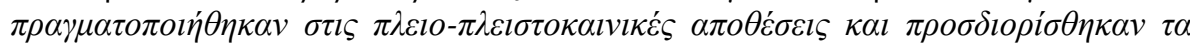

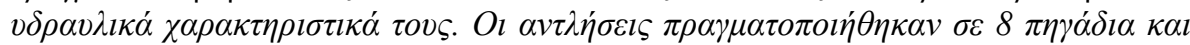

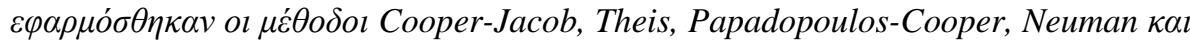

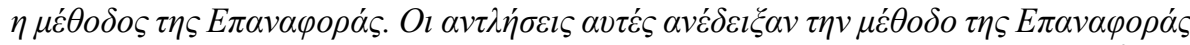

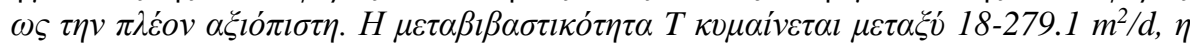

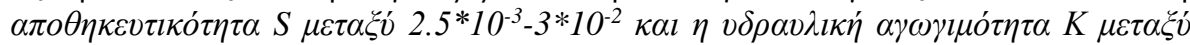

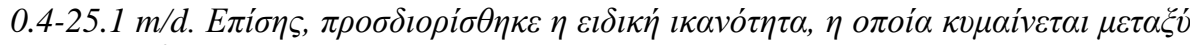

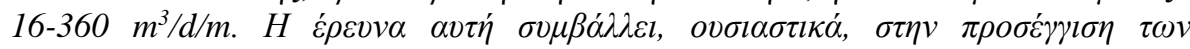

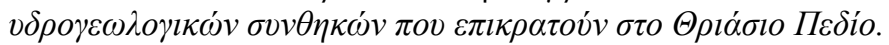

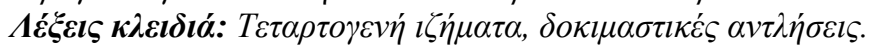




\section{Introduction}

Estimation of groundwater potential of an area is achieved by the determination of the hydrogeological regime as well as the calculation of hydraulic characteristics of the aquifers, transmissivity T, storativity $\mathrm{S}$ and hydraulic conductivity K. Specific capacity Q/s is of great value as well. The most reliable way to determine hydraulic parameters of the aquifer is pumping tests. In this way it is obtained an average value of these parameters as it is assumed that water moves through the total porosity (primary and secondary). The results from pumping tests outline the actual groundwater flow. This method is more accurate than the estimation of hydraulic parameters from laboratories measurements. These samples are never undisturbed (Driscoll, 1986). Many methods are used to analyze and evaluate pumping test data. Determination of the hydraulic characteristics is based on mathematical equations and analytical solutions. They are based also on the knowledge of geological structure and the processes that form aquifers as well as hydrogeological conditions that influence the variation of the piezometric level during the tests. These aquifers tests can also predict: a) the effect of new withdrawals on existing wells, b) the future drawdown in a well, c) the radius of influence of a well (Driscoll, 1986). In this article pumping tests in Plio-Pleistocene deposits of Thriassion Plain are represented. Hydraulic characteristics transmissivity T, storativity $\mathrm{S}$ and hydraulic conductivity $\mathrm{K}$ are assigned, using several methods and taking into account the average values (Driscoll, 1986; Kruseman et al., 1990). This study refers to the research of geohydraulic characteristics of the aquifers in Plio-Pleistocene deposits of Thriassion Plain for a better approach of hydrogeological conditions of the above area. Pumping test data are part of the doctoral thesis that is carried out in the above area (Hermides, 2016).

\section{Study area}

The geological structure of Thriassion is generally complex and has been affected at different times by many tectonic activities. The last ones acted in Pleistocene which caused horsts and grabens structures.

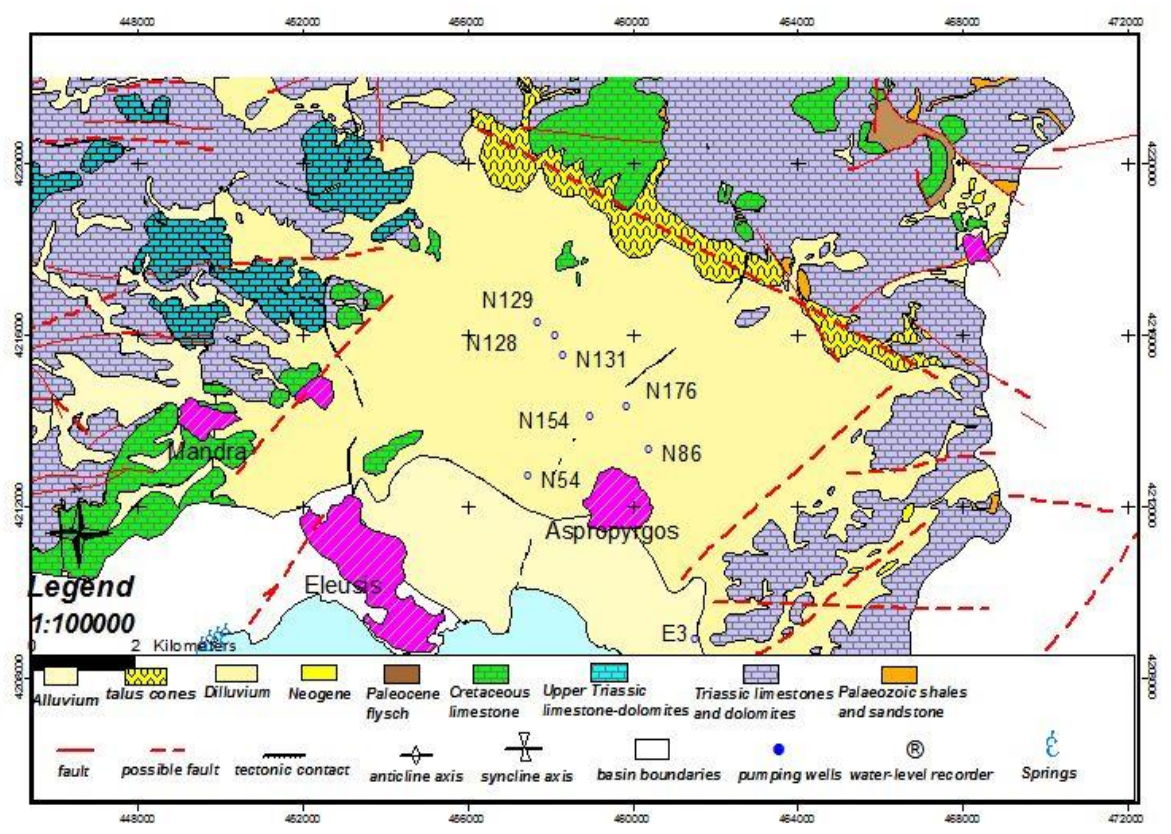

Figure 1 - Geological map of study area and points of pumping wells (IGME, Katsikatsos et al., 1986). 
The wide area consists of Palaeozoic volcano sedimentary complex of: a) clastic materials such argillaceous shales and sandstones, which alternate with grauwackes and conglomerates b)basicigneous volcanic rocks c) limestones, Triassic limestones and dolomites, Cretaceous limestones, Paleocene flysch, Plio-Pleistocene deposits of Pliocene marls, sandstone, marly limestone and Pleistocene argyles, sands, gravels, torrential fans of loosely and cohesive conglomerates and to the top alluvial deposits of argyles, loams, sands and gravels. The largest percentage of the wider area is mountainous with steep slopes and deep ravines, plains grow at altitudes from 0 to $100 \mathrm{~m}$, in Thriassion Plain, area of approximately $100 \mathrm{~km} 2$ presented by diluvium (Figure 1). This is a tectonic sinking which formatted during the Neogene and filled with terrestrial, lacustrine and marine deposits which thickness is over than $400 \mathrm{~m}$. Geologic and tectonic structures have influenced the hydrogeological conditions and the groundwater flow. Hydraulic characteristics of Plio-Pleistocene deposits differ throughout their extent. Pumping tests have been conducted by a few researchers in the past, in limestone and in quaternary deposits.

\section{Materials and Methods}

Pumping tests were carried out following most of the rules that required producing accurate data and determine as much as possible more actual values of the hydraulic characteristics of wells and the aquifer. The piezometric surface was at the normal static level, the discharge rate was constant and the water was piped far enough from pumping well, water level was recorded at regular intervals, the measuring of the drawdown was taken carefully, the measuring device was the same each time. Unsteady-state flow methods were used for both confined and unconfined aquifers. Theis's (1935) Cooper-Jacob's (1946), Neuman's (1972), Papadopulos-Cooper's (1967) methods were used as well the method of Recovery. The duration of pumping tests ranges between 6-12 hours, however, transmissivity is accurately determined. The methods presented in this article are based on the following assumptions (Theis, 1935):

1 The aquifer is confined and has an infinite extent.

2 The aquifer is homogeneous and isotropic and of uniform thickness around the area influenced by the pumping test.

3 Before the test, the piezometric surface is horizontal or nearly horizontal in the area affected by the test.

4 The aquifer is pumped at a constant discharge rate during the test.

5 The well penetrates the entire aquifer and receives water from the entire saturated thickness of the aquifer.

6 Water is been removed instantaneously from the aquifer by the pumping.

7 The aquifer is not supplied from any source during the test.

8 The flow towards the pumping well is horizontal.

9 The parameter $\mathrm{u}$, in the Cooper-Jacob's method, must be smaller than 0.01 .

10 The well diameter is small (not for Papadopoulos-Cooper method).

The main problem in the area of Thriassion focuses on the fact that the geological structure is complex and actual thickness of the aquifers cannot be accurately determined, because of the following:

- There are not several lithological cross-sections of wells in the area.

- None of such a well has penetrated the whole aquifer system.

- The thickness differs from site to site.

Therefore the following assumptions were adopted:

- The wells penetrate the entire thickness. This is not far from reality because thicknesses are small in general and one to three aquifers often is pumped.

- The total thickness of all aquifers is the sum of the individual aquifer thicknesses. 
- The thickness is uniform in the area influenced by the test, which is largely true.

For Cooper-Jacob's method the condition $\mathrm{u}<0.01$ is rather rigid. For 5 or 10 times higher value $\mathrm{u}<0.05$ or $\mathrm{u}<0.1$ the error introduced in the result is less than $2 \%$ or $5 \%$, respectively. For practical purposes it is suggested using $\mathrm{u}<0.05$ (Driscoll, 1986) or $\mathrm{u}<0.1$ (Kruseman et al., 1990). Specific capacity was calculated using the predicted drawdown s, after extension to 24 hours pumping, using the equation of the line regression from the graph or using the equation 1 of theoretical drawdown:

\section{Equation 1 theoretical drawdown $s$}

$\mathrm{s}=0.183 * \frac{\mathrm{Q}}{\mathrm{T}} * \log \left(2.25 * \frac{\mathrm{Qt}}{\mathrm{r}^{2} \mathrm{~S}} s=0.183 * \frac{Q}{T} * \log \left(2.25 * \frac{Q^{*} t}{r^{2} * S}\right)\right.$

In aquifers of Thriassion, pumping tests were conducted in the wells:

- $\quad$ N54, N86, N128, N129, N131, N154, N154 П-2, N176 by the writer

- in the group of the wells E (4 wells) by IGME

Many graphs were accomplished and all pumping data were analysed with all the methods and finally an average result of the calculations is presented to obtain as the most accurate values as possible (Kruseman et al., 1990).

\section{Results}

\subsection{Evaluation of pumping test data}

\subsubsection{Well Nr54}

The test was conducted on 05/29/2012, the duration of it was 12 hours and the drawdown was 0.86 $\mathrm{m}$. Thickness of the aquifer is $5 \mathrm{~m}$ data were analysed with all methods and finally, Papadopoulos's, Neuman's and the Recovery methods were chosen (Figure 2). The aquifer which is tapped by well $\mathrm{Nr} 54$ is unconfined. This is proved from the fact that the annual water level fluctuation is about $0.45 \mathrm{~m}$. The conditions around the well N54-П1 at distance $65 \mathrm{~m}$ faraway show confined aquifer and the well Nr54-П2 at distance $125 \mathrm{~m}$ faraway show semiconfined aquifer, as the storativity value deduced from analysis of the observing wells $\Pi 1$ and $\Pi 2$ ranges between $2.8 * 10-3$ and 9.8*10-3, respectively (Figure 3).
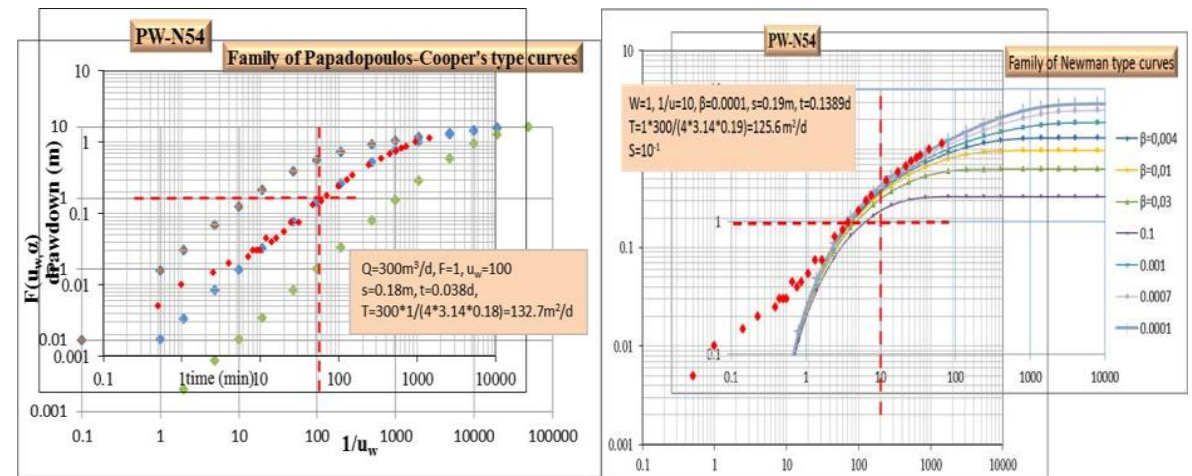

Figure 2 - Analysis of pumping test data of well N54 after Papadopulos-Cooper's and Neuman's method.

In Figure 3 it is shown a clear example of a transient steady-state flow. For an hour the drawdown of the two observation wells P1 and P2, located $60 \mathrm{~m}$ between them, have the same rate without reaching the equilibrium. In Figure 4 is shown pumping test data of the observation well P2 analyzed with Theis's method. In the same Figure 4 it shown a typical case where it could be given incorrect interpretation because it is displaced the phenomenon of pseudo-transmissivity where data are affected by storage effects (the first segment in Figure 3) and recharge effects (the horizontal 
segment) (Worthington, 1981). The value of transmissivity deduced after Papadopulos-Cooper's method was $\mathrm{T}=132.7 \mathrm{~m} 2 / \mathrm{d}$, after Neuman's method was $\mathrm{T}=125.6 \mathrm{~m} 2 / \mathrm{d}$ and by the Recovery method was $\mathrm{T}=129.1 \mathrm{~m} 2 / \mathrm{d}$. It is strongly obvious that $\mathrm{T}=129.1 \mathrm{~m} 2 / \mathrm{d}$ Storativity around the well $\mathrm{Nr} 54$ is $\mathrm{S}=6.2 * 10$-3revealing a semiconfined aquifer, hydraulic conductivity was $\mathrm{K}=25.1 \mathrm{~m} / \mathrm{d}$ and specific capacity was calculated $\mathrm{Q} / \mathrm{s}=294 \mathrm{~m} 3 / \mathrm{d} / \mathrm{m}$.

\subsubsection{Well Nr 86}

The test was conducted on 10/19/2011, the duration of it was 6 hours and the drawdown was $1.12 \mathrm{~m}$. Thickness of the aquifer is $15 \mathrm{~m}$ Data were analysed using all methods and finally, PapadopoulosCooper's, Cooper-Jacob's and the Recovery methods were chosen. In Figure 5 it appears a clear example of pumping test data where the storage effect in the well affected the discharge rate and if it is not been taken into account the estimation of transmissivity will be erroneous.

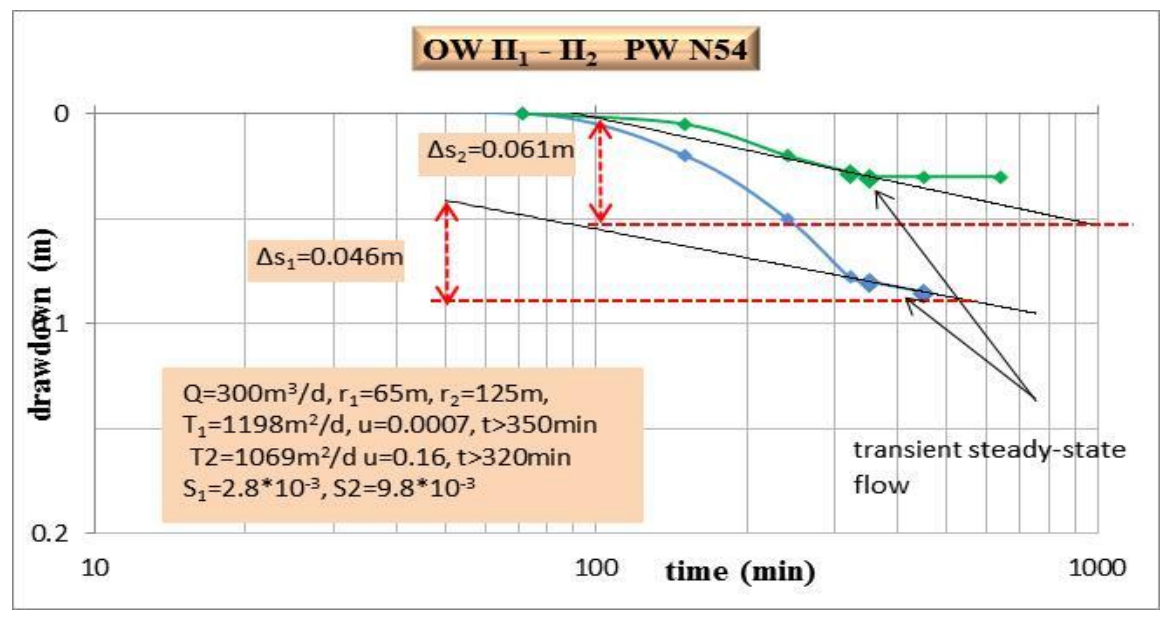

Figure 3 - Pumping test data for the observation wells П1-П2 and development of a transient steady-state flow (Cooper-Jacob's method).

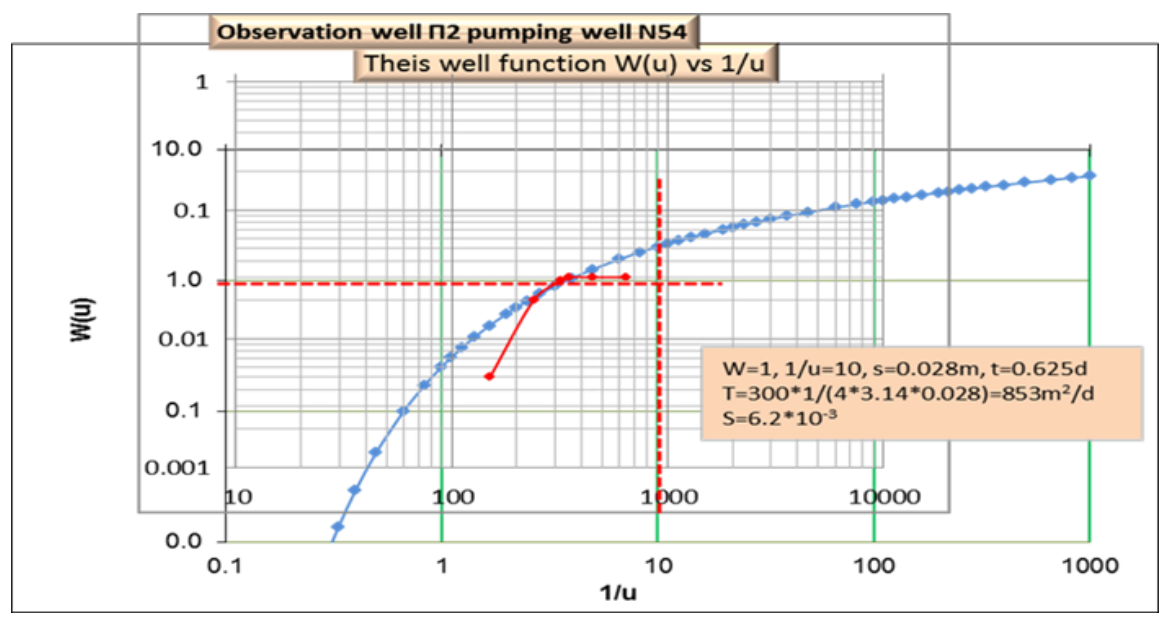

Figure 4 - Pumping test data of the observation well P2 and detection of pseudotransmissivity (Theis's method).

The value of transmissivity deduced after Papadopulos-Cooper's method was $\mathbf{T}=\mathbf{2 7 0 . 7} \mathbf{~ m 2 / d}$, after

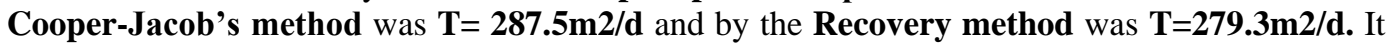

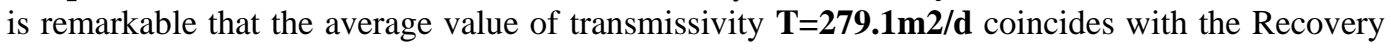
value. Storativity around the area of well $\mathrm{Nr} 86$ is $\mathbf{S}=\mathbf{5 . 3} * \mathbf{1 0 - 3}$ revealing a semiconfined aquifer, 
hydraulic conductivity was $\mathbf{K}=\mathbf{2 3 . 2 5} \mathbf{~ m} / \mathbf{d}$ and specific capacity was calculated at $\mathbf{Q} / \mathbf{s = 3 0 0 ~} \mathbf{~ m 3 / d / m}$. Storage effects in the pumping well has been analysed by Schafer's equation 2 (Schafer, 1978).

Equation 2 Schafer's equation of calculating time t when storage in the well is negligible

$\left.\boldsymbol{t}_{c}=0.017 \frac{\left(d_{c}^{2}-d_{p}^{2}\right)}{\frac{Q}{s}}\right)$

Where:

$t_{c}=$ time when storage effect in the well becomes negligible in minute

$\mathrm{d}_{\mathrm{c}}=$ diameter of unscreened well in $\mathrm{mm}$

$\mathrm{d}_{\mathrm{p}}=$ outside diameter of pump pipe in $\mathrm{mm}$

$\mathrm{Q} / \mathrm{s}=$ specific capacity in $\mathrm{m}^{3} / \mathrm{d} / \mathrm{m}$

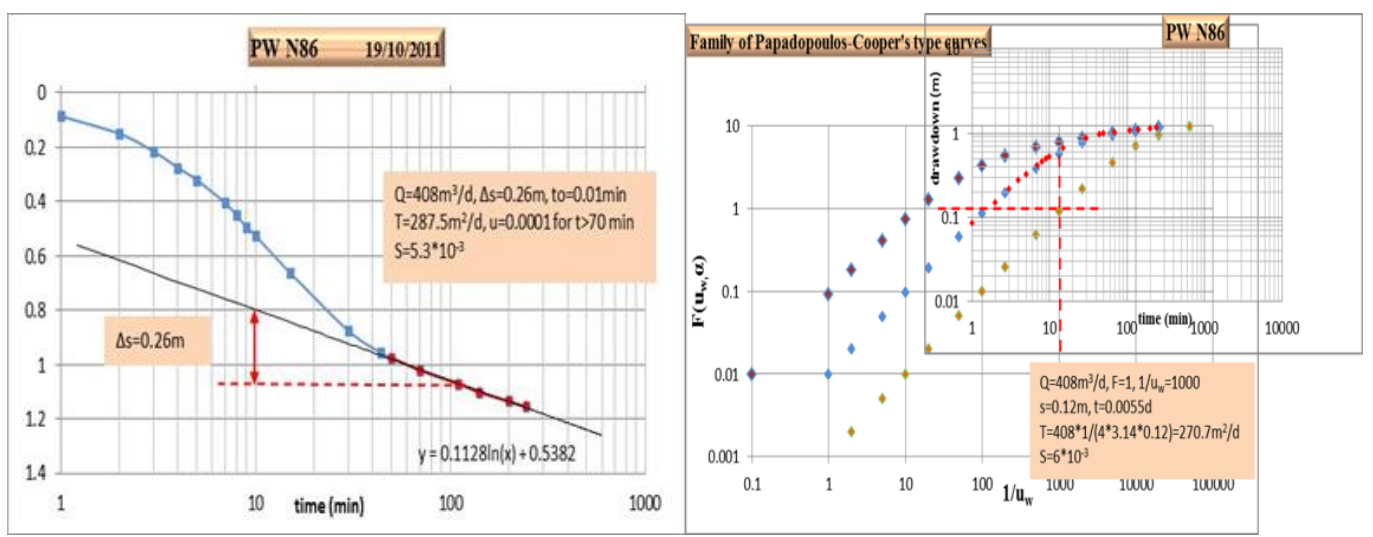

Figure 5 - Pumping test data of the pumping well Nr 86 (Cooper-Jacob's and PapadopulosCooper's method).

\subsubsection{Well $\mathrm{Nr} 128$}

The test was conducted on 10/28/2008, the duration of it was 6 hours and the drawdown was $6.77 \mathrm{~m}$. Thickness of the aquifer is $15 \mathrm{~m}$. Data were analysed using all methods and finally, PapadopulosCooper's, Neuman's, Cooper-Jacob's and Recovery methods were chosen. The value of transmissivity deduced after Theis's method was $\mathbf{T}=\mathbf{2 5 . 5} \mathbf{~ m 2 / d}$, after Neuman's method was $\mathbf{T}=$ $\mathbf{2 2 . 5 m}$ 2/d (Figure 6), after Papadopulos-Cooper's method $\mathbf{T}=\mathbf{3 4 . 7} \mathbf{m} 2 / \mathbf{d}$ and by the Recovery method was $\mathbf{T}=\mathbf{3 0 . 1} \mathbf{m} \mathbf{2} / \mathbf{d}$ (Figure 7 ). Transmissivity value is finally $\mathbf{T}=\mathbf{3 0 . 1} \mathbf{m} \mathbf{2} / \mathbf{d}$. Hydraulic conductivity calculated at the value of $\mathbf{K = 2} \mathbf{m} / \mathbf{d}$ and specific capacity at the value of $\mathbf{Q} / \mathbf{s = 5 2} \mathbf{m} \mathbf{3} / \mathbf{d} / \mathbf{m}$. Papadopulos-Cooper's method gave a value of storativity $\mathbf{S}=\mathbf{1 . 9} * \mathbf{1 0 - 2}$. This value reveals an unconfined aquifer; however the aquifer is under pressure in general, which is proved by the high piezometric level of $+9.5 \mathrm{~m}$ and the annual fluctuation of about $5 \mathrm{~m}$. The answer in this discrepancy of results is that the time of pumping in October the aquifer behaved as unconfined due to the generally drawdown of the piezometric surface.

\subsubsection{Well Nr 129}

The test was conducted on 10/29/2008, the duration of it was 5 hours and the drawdown was $6.77 \mathrm{~m}$. The thickness of the aquifer is about $15 \mathrm{~m}$. The estimated value of transmissivity taking into account the Theis's, Cooper-Jacob's and Recovery methods was $\mathbf{T}=\mathbf{1 8} \mathbf{~} \mathbf{2} / \mathbf{d}$. This value of transmissivity combined with the large drawdown of about $10 \mathrm{~m}$ reveals an aquifer of low capacity and it is very likely to locate at the border of the Plio-Pleistocene deposits. Hydraulic conductivity calculated at the value of $K=\mathbf{0 . 4} \mathbf{m} / \mathbf{d}$ and specific capacity at value $Q / \mathrm{s}=\mathbf{1 6} \mathbf{m} 3 / \mathrm{d} / \mathbf{m}$. 


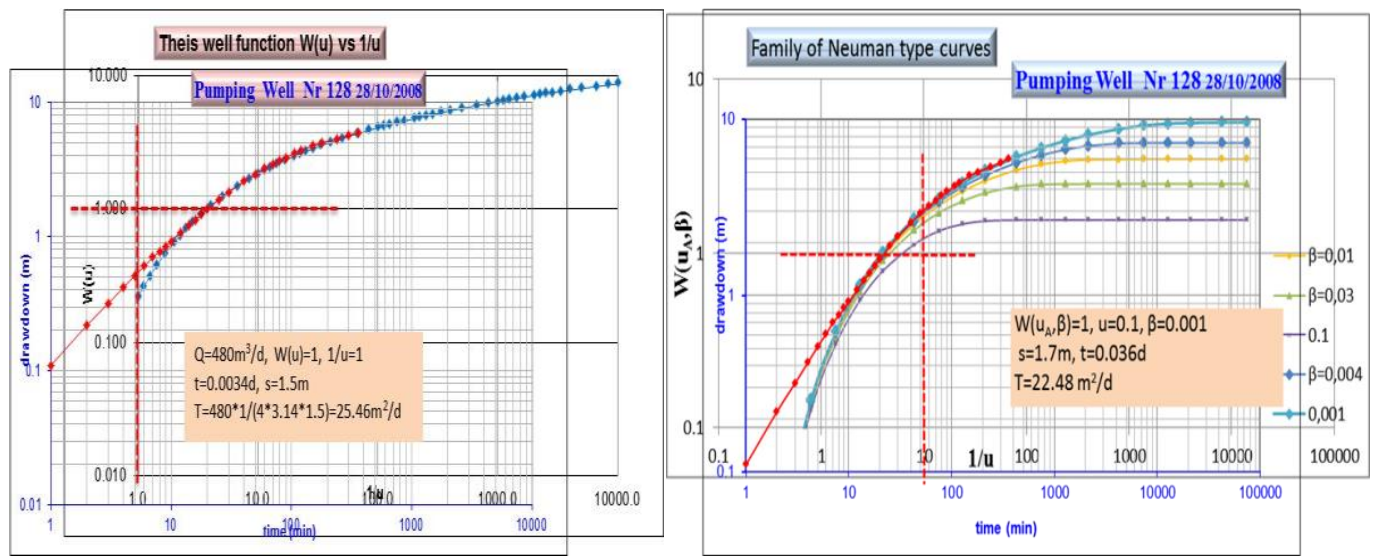

Figure 6 - Pumping test data of well Nr 128 (Cooper-Jacob's and Neuman's method).

\subsubsection{Well Nr 131}

The test was conducted on 10/28/2008, the duration of it was 5 hours and the drawdown was $2.44 \mathrm{~m}$. The thickness of the aquifer is about $15 \mathrm{~m}$ and pumping test data have been taken only by the recovery phase. Transmissivity value was estimated at the value of $\mathbf{T}=\mathbf{3 2 . 5 2} \mathbf{m} 2$ /d (Figure $8 \mathrm{a}$ ). Drawdown was $4.66 \mathrm{~m}$ after 5 hours pumping. Discharge rate was $\mathbf{Q}=\mathbf{4 0 8} \mathbf{~ m 3 / d}$. Aquifer is confined and the piezometric level is at $+9 \mathrm{~m}$. Specific capacity was estimated the value of $\mathbf{Q} / \mathbf{s}=$ $50 \mathrm{~m} 3 / \mathrm{d} / \mathrm{m}$.

\subsubsection{Well Nr 154}

The test was conducted on 04/05/2009, the duration of it was 6 hours and the drawdown was $1.31 \mathrm{~m}$ The thickness of the aquifer is about $10 \mathrm{~m}$. Transmissivity value obtained after Theis's method was $\mathbf{T}=\mathbf{1 0 4 . 6} \mathbf{~ m 2} / \mathbf{d}$, after Cooper-Jacob's method was $\mathbf{T}=104.7 \mathrm{~m} 2 / \mathrm{d}$, by the Recovery method was $\mathbf{T}$ $\mathbf{1 0 5 . 4} \mathbf{~ m 2} / \mathbf{d}$ and after Neuman's method $\mathbf{T}=\mathbf{1 0 8 . 3 m} 2 / \mathbf{d}$. The average value was $\mathbf{T}=\mathbf{1 0 5 . 8 m 2 / d}$. Drawdown was $1.31 \mathrm{~m}$ after 6 hours pumping. The aquifer is unconfined and storativity obtained after Papadopulos-Cooper's method $\mathbf{S}=\mathbf{2 . 8} * \mathbf{1 0 - 2}$. Hydraulic conductivity $\mathbf{K}=\mathbf{1 0 . 5 8} \mathbf{m} / \mathbf{d}$ (Figure $8 b)$. Specific capacity was calculated at the value of $Q / s=247 \mathbf{m 3} / \mathbf{d} / \mathbf{m}$.

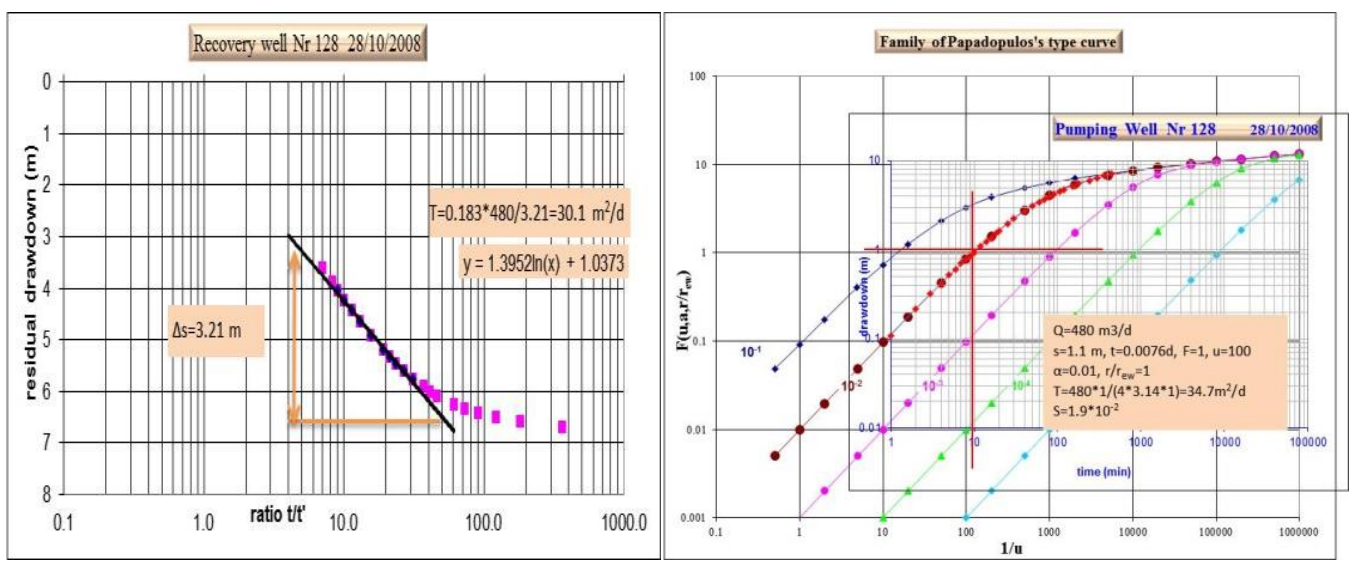

Figure 7 - Pumping test data of well Nr 128 (Recovery, Papadopulos-Cooper's methods).

\subsubsection{Well Nr 154-П2}

The test was conducted on 04/05/2009, the duration of it was 3 hours because the pump was broken and the drawdown was $1.29 \mathrm{~m}$. Transmissivity value obtained after Papadopulos-Cooper's method 
was $\mathbf{T}=\mathbf{2 2 8} \mathbf{~ m 2 / d}$, by Recovery method $\mathbf{T}=\mathbf{2 3 8 . 6} \mathbf{~} \mathbf{2} / \mathbf{d}$ and Neuman's method $\mathbf{T}=\mathbf{2 2 8 . 3 m} 2 / \mathbf{d}$. The average value $\mathbf{T}=\mathbf{2 3 1 . 6 m} 2 / \mathbf{d}$. Drawdown was $1.255 \mathrm{~m}$ after 3 hours pumping. The aquifer is unconfined and storativity is $S=3 * \mathbf{1 0 - 2}$. Hydraulic conductivity $K=\mathbf{1 5 . 4 4} \mathbf{~ m} / \mathbf{d}$. Discharge rate was $\mathbf{Q}=\mathbf{5 1 6} \mathbf{~ m 3 / d}$ (Figure 9). Specific capacity was estimated at the value of $Q / \mathbf{s}=\mathbf{3 6 0} \mathbf{~ m 3 / d} / \mathbf{m}$.

\subsubsection{Well Nr 176}

The test was conducted on 10/02/2000, the duration of it was 5 hours and the drawdown was $3.86 \mathrm{~m}$. Transmissivity value obtained after Papadopulos-Cooper's method was $\mathbf{T}=\mathbf{5 7 . 3} \mathbf{~ m 2 / d}$, after Recovery method $\mathbf{T}=\mathbf{5 6 . 7} \mathbf{m} \mathbf{2} / \mathbf{d}$ and Neuman's method $\mathbf{T}=\mathbf{5 2 . 1 m} \mathbf{2} / \mathbf{d}$. The average value was $\mathbf{T}=\mathbf{5 5 . 4 m 2 / d}$. Drawdown was $3.86 \mathrm{~m}$ after 5 hours of pumping. The aquifer is confined and storativity is $S=\mathbf{2 . 5} * \mathbf{1 0 - 3}$. Hydraulic conductivity $K=\mathbf{1 1 . 0 8} \mathbf{~ m} / \mathbf{d}$. Discharge rate was $Q=\mathbf{7 2 0} \mathbf{~ m} / \mathbf{d}$ (Figure 10).

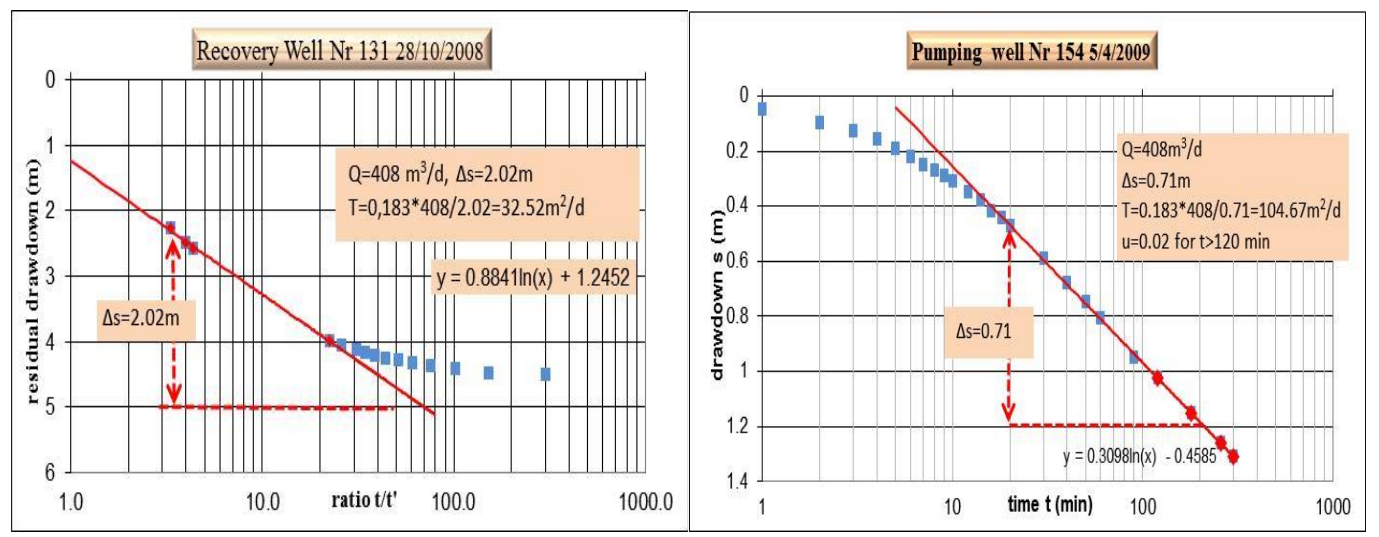

Figure 8 a, b - Pumping test data of well Nr 131 and Nr 154 (Recovery and Cooper-Jacob's method respectively).

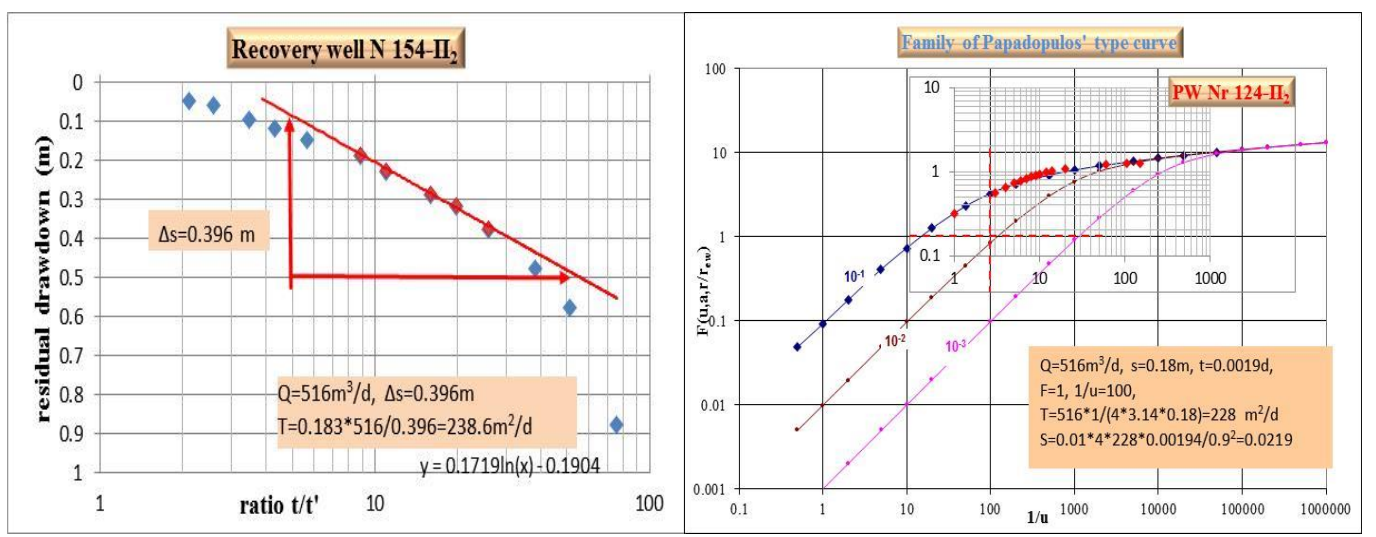

Figure 9 - Pumping test data of well Nr 154-P2 (Recovery and Papadopulos-Cooper's method respectively). 

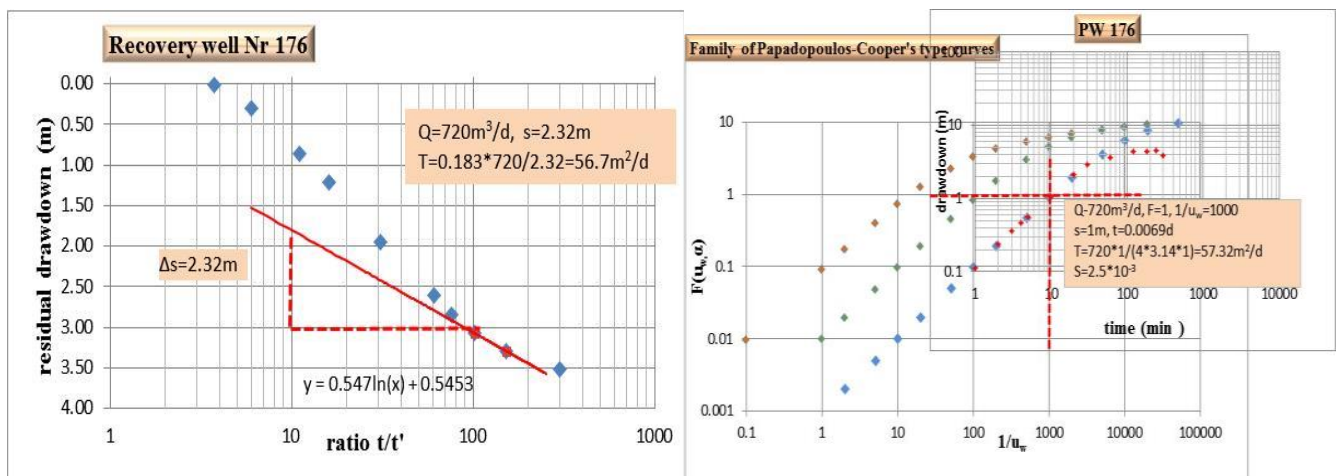

Figure 10 - Pumping test data of well Nr 176 (Recovery and Papadopulos-Cooper's method respectively).

Table 1 summarizes the hydraulic characteristics of 8 wells that have been pumped in Thriassion Plain.

Table 11 - Summary of hydraulic characteristics of wells in Plio-Pleistocene deposits of Thriassion Plain.

\begin{tabular}{|c|c|c|c|c|}
\hline Well Nr & $T\left(\mathrm{~m}^{2} / \mathrm{d}\right)$ & $\mathbf{S}$ & $\mathbf{K}(\mathbf{m} / \mathbf{d})$ & $\begin{array}{c}\text { Calculated } 24 \mathrm{~h} \\
\mathrm{Q} / \mathrm{s}\left(\mathrm{m}^{3} / \mathrm{d} / \mathrm{m}\right)\end{array}$ \\
\hline N54 & 129.1 & & 25.1 & 294 \\
\hline N54-П2 & & $2.8^{*} 10^{-3}$ & & \\
\hline N86 & 279.1 & $5.3^{*} 10^{-3}$ & 23.25 & 300 \\
\hline N128 & 30.1 & $1.9 * 10^{-2}$ & 2 & 52 \\
\hline N129 & 18 & & 0.4 & 16 \\
\hline N131 & 32.52 & & 2.17 & \\
\hline N154 & 105.8 & $2.8^{*} 10^{-2}$ & 10.58 & 247 \\
\hline N154-П2 & 231.6 & $3 * 10^{-2}$ & 15.44 & 360 \\
\hline N176 & 55.4 & $2.5 * 10^{-3}$ & 11.08 & 186 \\
\hline average & 110.2 & & 11.25 & 207.86 \\
\hline
\end{tabular}

\section{Conclusions}

This study presents pumping tests in wells in Plio-Pleistocene deposits of Thriassion Plain of Attica which conducted in the period 2008-2012 and one test in 2000. None of important changes in climatic conditions or other environmental impacts occurred during this period that could affect the hydraulic characteristics of Triasssion Plain. Concluding after all these data, it is obvious that the aquifers, in the above mentioned area, are under unconfined, confined and semi confined conditions. These results are actually reasonable in terrestrial Pleistocene deposits within there are clay layers. The values of transmissivity $\mathrm{T}$ ranges from $\mathbf{8 - 2 7 9 . 1} \mathrm{m} \mathbf{2} / \mathrm{d}$, storativity $\mathrm{S}$ ranges from $\mathbf{2 . 5} * \mathbf{1 0 - 3}-\mathbf{3} * \mathbf{1 0}$ 2, hydraulic conductivity $K$ ranges from $\mathbf{0 . 4 - 2 5 . 1 ~ m / d ~ a n d ~ s p e c i f i c ~ c a p a c i t y ~} Q / s$ ranges from 16-360 $\mathrm{m} 3 / \mathbf{d} / \mathbf{m}$.

\section{References}

Cooper, H.H.Jr. and Jacob, C., 1946. A generalized graphical method for evaluating formations constants and summarizing well-field history, Trans. Amer. Geophysical Union, 27, 526-534. 
Driscoll, F., 1986. Groundwater and wells $2^{\text {nd }}$ edition, 1089 pp., Johnson Div. publication.

Hermides, D., 2016. Hydrogeological conditions of the Thriassion Plain Basin with emphasis on the geohydraulic characteristics of the aquifers and the groundwater quality, (In print).

IGME, Katsikatsos, G., Mettos, A., Vidakis, M., Dounas, A., Pomoni, F., Tsaila-Monopolis, S. and Skourtsi-Koroneou, V., 1986. Geological map of Greece, Sheet of Thriassion, IGME publication, Athens.

Kruseman, G. and de Ridder, N., 1990. Analysis and Evaluation of Pumping test Data, $2^{\text {nd }}$ edition, $377 \mathrm{pp}$.

Neuman, S.P., 1972. Theory of flow in unconfined aquifers considering delayed response of the water table, Water Resources Research, 8, 1031-1045.

Papadopoulos, I.S. and Cooper, H.Jr., 1967. Drawdown in a well of large diameter, Water Resources Research, 3, 241-244.

Paraschoudes, B., 2002. Hydrogeological study of Westrern Attica, Ministry of Agricultural Department of Geology and Hydrology, unpublished report Athens.

Schafer, D.C., 1978. Casing Storage can affect Pumping Test Data, Johnson Drillers' Journal, Jan/Feb, Johnson Division, UOP Inc, St. Paul, Minnesota.

Theis, C.V., 1935. The relation between the lowering of the piezometric surface and the rate and duration of discharge of a well using ground water storage, Trans. Amer, Geophysical Union, $16,519-524$

Worthington, P.F., 1981. Estimation of the transmissivity of thin leaky-confined aquifers from single-well pumping tests, Journal of Hydrology, 49, 19-30. 